\title{
Functional Diversity of Subicular Principal Cells during Hippocampal Ripples
}

\author{
Claudia Böhm, ${ }^{1}$ Yangfan Peng, ${ }^{2}$ Nikolaus Maier, ${ }^{1}$ Jochen Winterer, ${ }^{1}$ James F.A. Poulet, ${ }^{1,3,4}$ Jörg R.P. Geiger, ${ }^{2,4}$ \\ and Dietmar Schmitz ${ }^{1,3,4,5,6}$ \\ ${ }^{1}$ Neuroscience Research Center and ${ }^{2}$ Institute of Neurophysiology, Charité Universitätsmedizin Berlin, 10117 Berlin, Germany, ${ }^{3}$ Max-Delbrück Center for \\ Molecular Medicine, 13092 Berlin, Germany, ${ }^{4}$ Cluster of Excellence NeuroCure, 10117 Berlin, Germany, ${ }^{5}$ Bernstein Center for Computational Neuroscience, \\ 10115 Berlin, Germany, and ${ }^{6}$ Center for Neurodegenerative Diseases Berlin, 10117 Berlin, Germany
}

Cortical and hippocampal oscillations play a crucial role in the encoding, consolidation, and retrieval of memory. Sharp-wave associated ripples have been shown to be necessary for the consolidation of memory. During consolidation, information is transferred from the hippocampus to the neocortex. One of the structures at the interface between hippocampus and neocortex is the subiculum. It is therefore well suited to mediate the transfer and distribution of information from the hippocampus to other areas. By juxtacellular and whole-cellrecordings in awake mice, we show here that in the subiculum a subset of pyramidal cells is activated, whereas another subset is inhibited during ripples. We demonstrate that these functionally different subgroups are predetermined by their cell subtype. Bursting cells are selectively used to transmit information during ripples, whereas the firing probability in regular firing cells is reduced. With multiple patch-clamp recordings in vitro, we show that the cell subtype-specific differences extend into the local network topology. This is reflected in an asymmetric wiring scheme where bursting cells and regular firing cells are recurrently connected among themselves but connections between subtypes exclusively exist from regular to bursting cells. Furthermore, inhibitory connections are more numerous onto regular firing cells than onto bursting cells. We conclude that the network topology contributes to the observed functional diversity of subicular pyramidal cells during sharp-wave associated ripples.

Key words: connectivity; hippocampus; in vivo; multiple recordings; oscillation; subiculum

Significance Statement

Memory consolidation is dependent on hippocampal activity patterns, so called hippocampal ripples. During these fast oscillations, memory traces are transferred from the hippocampus to the neocortex via the subiculum. We investigated the role of single cells in the subiculum during ripples and found that, dependent on their subtype, they are preferentially activated or inhibited. In addition, these two subtypes, the bursting and regular firing type, are differentially integrated into the local network: inhibitory cells are more densely connected to regular firing cells, and communication between regular and bursting cells is unidirectional. Together with earlier findings on different preferential target regions of these subtypes, we conclude that memory traces are guided to target regions of the activated cell type.

\section{Introduction}

The hippocampal formation exhibits robust networks oscillations, which are correlated to different behavioral states (O'Keefe and Nadel, 1978). Sharp-wave associated ripples (SWRs) are ob- served during slow-wave sleep, awake immobility, and consummatory behavior (O'Keefe and Nadel, 1978; Buzsáki, 1986). They are related to memory consolidation in rodents and primates (Girardeau et al., 2009; Ego-Stengel and Wilson, 2010; Logothetis

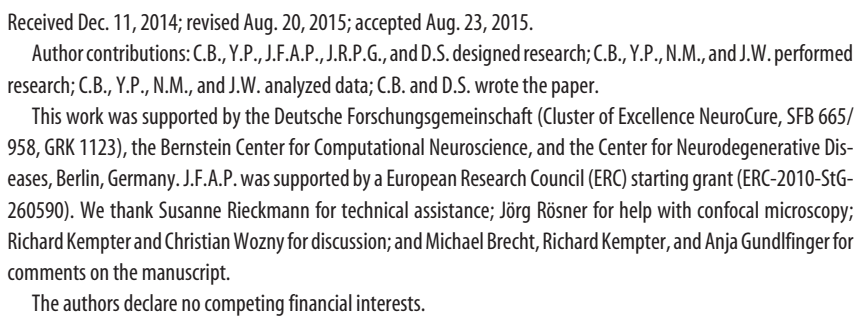
eases, Berlin, Germany. J.F.A.P. was supported by a European Research Council (ERC) starting grant (ERC-2010-StG260590). We thank Susanne Rieckmann for technical assistance; Jörg Rösner for help with confocal microscopy; Richard Kempter and Christian Wozny for discussion; and Michael Brecht, Richard Kempter, and Anja Gundlfinger for comments on the manuscript.

The authors declare no competing financial interests.

This article is freely available online through the J Neurosci Author Open Choice option.

Correspondence should be addressed to either of the following: Dietmar Schmitz, Charitéplatz 1, 10117 Berlin, Germany, E-mail: dietmar.schmitz@charite.de; or Claudia Böhm, Howard Hughes Medical Institute, Janelia Research Campus, Ashburn, VA 20147, E-mail: boehmc@janelia.hhmi.org.

C. Böhm's current address: Howard Hughes Medical Institute, Janelia Research Campus, Ashburn, VA 20147.

DOI:10.1523/JNEUROSCI.5034-14.2015

Copyright $\odot 2015$ Böhm et al.

This is an Open Access article distributed under the terms of the Creative Commons Attribution License Creative Commons Attribution 4.0 International, which permits unrestricted use, distribution and reproduction in any medium provided that the original work is properly attributed. 
et al., 2012; Jadhav et al., 2012; Inostroza and Born, 2013) and occur temporally correlated in respective areas of the hippocampal formation, including the subiculum (Chrobak and Buzsáki, 1994). Concomitantly, during SWR, subcortical areas involved in sensory processing are silenced, thereby minimizing interference in hippocampal-neocortical interaction and enabling an efficient information transfer (Logothetis et al., 2012). These findings are in line with the beneficial effect of slow-wave sleep in memory consolidation (Marshall et al., 2006; Inostroza and Born, 2013; Wilhelm et al., 2013). At the cellular level, the consolidation of memory traces during SWR is thought to be based on the reactivation of neuronal ensembles that have been activated during exploration in a temporally compressed fashion (Lee and Wilson, 2002; Davidson et al., 2009; Karlsson and Frank, 2009), thereby stabilizing the synaptic connections between ensemble members (Markram et al., 1997) not only within the hippocampus but also in the cortex (Ji and Wilson, 2007; Mehta, 2007). One of the major output areas of the hippocampus is the subiculum (Witter, 2006). It is densely innervated by the CA1 region of the hippocampus in a series of nested loops (Amaral et al., 1991) and sends projections to various cortical and subcortical structures in a topographic fashion (Witter et al., 1990; Naber et al., 2000; Witter, 2006). In contrast to CA1 pyramidal cells, subicular pyramidal cells exhibit a low degree of axonal collateralization and project mostly to only one target region (Naber and Witter, 1998; Kim and Spruston, 2012). In vitro, two types of pyramidal cells have been described in the subiculum: regular firing cells and intrinsically bursting cells (for review, see Behr et al., 2009). These cells have been shown to display different properties with respect to pharmacological responsiveness, dendritic morphology, and projection area (Kim and Spruston, 2012; Graves et al., 2012). However, it remains unclear whether these subtypes are also functionally diverse and whether this diversity is reflected in the local network topology. To address these questions, we combined single-cell in vivo electrophysiology during a defined behavioral state with multiple simultaneous patch-clamp recordings in vitro. This allowed us to reveal a pyramidal cell subtype-specific activation during SWR and a local synaptic circuitry that exhibits unidirectional connectivity from regular to bursting cells as well as an inhibitory circuitry that favors inhibition onto regular firing cells.

\section{Materials and Methods}

\section{Ethics statement}

Animal maintenance and experiments were in accordance with the respective guidelines of local authorities (Berlin state government, T0100/03 and G0151/12) and followed the German animal welfare act and the European Council Directive 2010/63/EU on protection of animals used for experimental and other scientific purposes.

\section{Animal surgery and electrophysiology in vivo}

All in vivo experimental procedures followed previously described methods (Crochet and Petersen, 2006; Maier et al., 2011). Male p24 to p33 C57BL/6J mice were anesthetized and implanted with a lightweight metal head holder and a plastic recording chamber centered over the CA1subicular region. After surgery, animals were allowed to recover for at least $1 \mathrm{~d}$ before habituation to head restraint started. Habituation was repeated for several days until the animal sat calmly for a period of at least $1 \mathrm{~h}$. On the day of the experiment, two small craniotomies for local field potential (LFP) and single-cell recordings were made under isoflurane anesthesia (1.5\%). Animals were then allowed to recover for at least $2 \mathrm{~h}$ before recordings started. Coordinates for craniotomies were determined stereotactically on the left hemisphere: for LFP recordings in distal CA1, the glass pipette was inserted at $2.5 \mathrm{~mm}$ posterior of bregma and 2.5 $\mathrm{mm}$ medial from the midline at an angle of $\sim 30$ degree tilted from the vertical. The patch electrode was inserted vertically $3 \mathrm{~mm}$ posterior of bregma and 1.8-2 mm lateral of the midline. For LFP recordings, we used glass pipettes (5-7 $\mathrm{M} \Omega$ ) filled with Ringer's solution containing the following (in mM): $135 \mathrm{NaCl}, 5 \mathrm{KCl}, 5 \mathrm{HEPES}, 1.8 \mathrm{CaCl}_{2}$, and $1 \mathrm{MgCl}_{2}$. To determine the recording depth of the area of interest (i.e., CA1 stratum pyramidale), the LFP electrode was lowered until clear ripple activity was observed, usually at $1100-1300 \mu \mathrm{m}$. Then the second electrode was inserted through the more posterior craniotomy, aimed to target the subiculum. It was advanced until signal polarity of both electrodes was equal and ripple activity could also be seen on the subiculum electrode (at $\sim 1500 \mu \mathrm{m}$ ). Searching for cells began $\sim 50 \mu \mathrm{m}$ above the so-determined depth with a new pipette. For whole-cell and juxtacellular recordings, 5-7 $\mathrm{M} \Omega$ glass electrodes filled with intracellular solution containing the following (in $\mathrm{mm}$ ): $135 \mathrm{~K}$-gluconate, $4 \mathrm{KCl}, 4 \mathrm{MgATP}, 10 \mathrm{Na}_{2}$ phosphocreatine, $0.3 \mathrm{Na}_{3} \mathrm{GTP}$, and 10 HEPES ( $\mathrm{pH}$ adjusted to 7.3 with $\mathrm{KOH} ; 2 \mathrm{mg} / \mathrm{ml}$ biocytin).

No constant current injections were used. Membrane potentials are not corrected for liquid junction potential. On average, the initial membrane potential was $-59.8 \pm 0.7 \mathrm{mV}$ (mean \pm SEM, $n=46$ cells), and the average spike height was $70.3 \pm 2.2 \mathrm{mV}$ (mean $\pm \mathrm{SEM}, n=46$ cells) as calculated at rheobase from baseline voltage before current injection to spike peak. Cells with an initial membrane potential positive to $-50 \mathrm{mV}$ were excluded. Recording positions in the subiculum were verified by biocytin staining of the recorded cell, an electrode track, or traces of ejected biocytin. All in vivo signals were amplified with a Multiclamp 700B (Molecular Devices), filtered at $10 \mathrm{kHz}$, and digitized at $20 \mathrm{kHz}$ (ITC-18; HEKA Elektronik). The reconstruction of the pyramidal cell shown in Figure $3 A$ was performed on a DAB staining of the biocytinfilled neuron using the Neurolucida software (MicroBrightField).

\section{Electrophysiology in vitro: slice preparation}

Male C57BL/6N mice of age 3-6 weeks were decapitated following isoflurane anesthesia. Brains were transferred to ice-cold ACSF slicing solution containing (in $\mathrm{mM}$ ) the following: $87 \mathrm{NaCl}, 2.5 \mathrm{KCl}, 3 \mathrm{MgCl}_{2}, 0.5$ $\mathrm{CaCl}_{2}, 25$ glucose, 50 sucrose, $1.25 \mathrm{NaH}_{2} \mathrm{PO}_{4}$, and $26 \mathrm{NaHCO}_{3}, \mathrm{pH}$ 7.4. Horizontal slices ( $400 \mu \mathrm{m}$ thick) of ventral to mid-hippocampus were cut on a slicer (VT1200S; Leica) and stored in an interface chamber $\left(32^{\circ} \mathrm{C}-34^{\circ} \mathrm{C}\right.$ ) and perfused with standard ACSF containing (in mM) the following: $119 \mathrm{NaCl}, 2.5 \mathrm{KCl}, 1.3 \mathrm{MgCl}_{2}, 2.5 \mathrm{CaCl}_{2}, 10$ glucose, 1.0 $\mathrm{NaH}_{2} \mathrm{PO}_{4}$, and $26 \mathrm{NaHCO}_{3}$. The perfusion rate was $\sim 1 \mathrm{ml} / \mathrm{min}$. All ACSF was equilibrated with carbogen $\left(95 \% \mathrm{O}_{2}, 5 \% \mathrm{CO}_{2}\right)$. Slices were allowed to recover for at least $1 \mathrm{~h}$ after preparation. Minislices of the subiculum were prepared from full slices and cut shortly after preparation on an agar block in oxygenized ACSF. A scalpel was used to separate both: connections between CA1 and the subiculum, and between the subiculum and the entorhinal cortex. After cutting, the slices were retransferred to the interface chamber and allowed to recover for at least $1 \mathrm{~h}$. In some experiments, subiculum minislices were cut immediately before the experiments. Data obtained from either approach were pooled.

\section{Recordings of ripple-associated currents in vitro}

As described previously (Maier et al., 2009), recordings were performed in standard ACSF at $31^{\circ} \mathrm{C}-32^{\circ} \mathrm{C}$ in a submerged-type recording chamber perfused at high rate $(5-6 \mathrm{ml} / \mathrm{min})$. For LFP recordings, glass microelectrodes (tip diameter $5-10 \mu \mathrm{m}$; resistance $0.2-0.3 \mathrm{M} \Omega$ ) were filled with ACSF before use. Whole-cell recordings of subicular principal neurons and interneurons were performed with glass electrodes $(2-5 \mathrm{M} \Omega)$ filled with 120 mm K-gluconate, 10 mM HEPES, 3 mм Mg-ATP, 10 mm KCl, 5 mM EGTA, $2 \mathrm{~mm} \mathrm{MgSO}_{4}, 0.3 \mathrm{~mm} \mathrm{Na}_{2}$-GTP, and 14 mм phosphocreatine. The $\mathrm{pH}$ was adjusted to 7.4 with $\mathrm{KOH}$. Voltage-clamp recordings at the reversal potential of excitation and inhibition were performed using intracellular solution containing $120 \mathrm{~mm}$ gluconic acid, $10 \mathrm{~mm}$ HEPES, 5 mм EGTA, $10 \mathrm{~mm} \mathrm{KCl,} 2 \mathrm{~mm} \mathrm{MgSO}_{4}, 1 \mathrm{~mm} \mathrm{Na}$-GTP, and $3 \mathrm{MgATP}$. The $\mathrm{pH}$ was adjusted to 7.4 with $\mathrm{CsOH}$. Using the Multiclamp 700A amplifier (Molecular Devices), extracellular LFP signals were amplified 1000-fold, and whole-cell data were amplified 5- and 25-fold for voltage-clamp and current-clamp recordings. Signals were filtered $(1-8 \mathrm{kHz})$ and digitized at 10 or $20 \mathrm{kHz}$ with 16-bit resolution (6036 E card; National Instruments); 
A

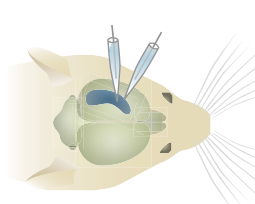

B

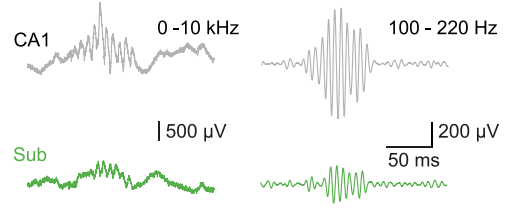

C

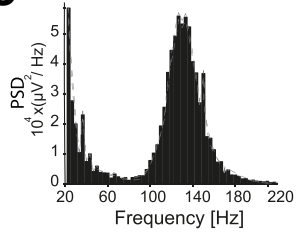

D1
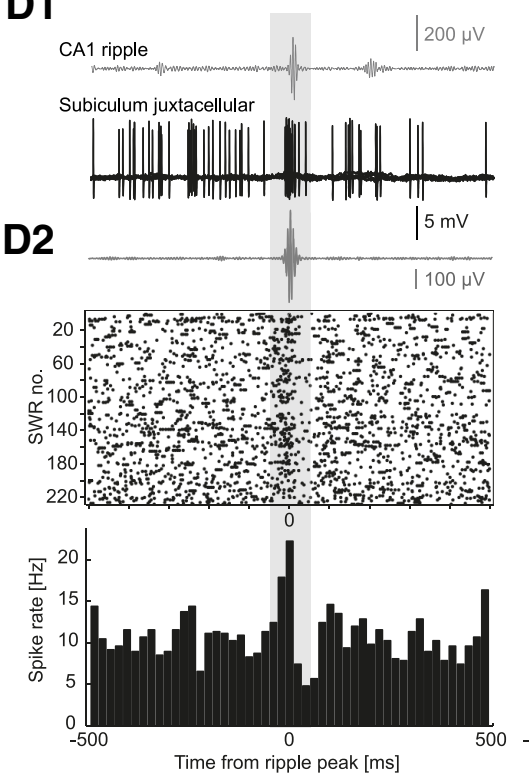

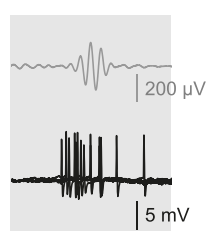

E1
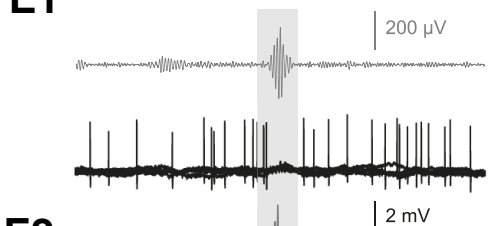

E2
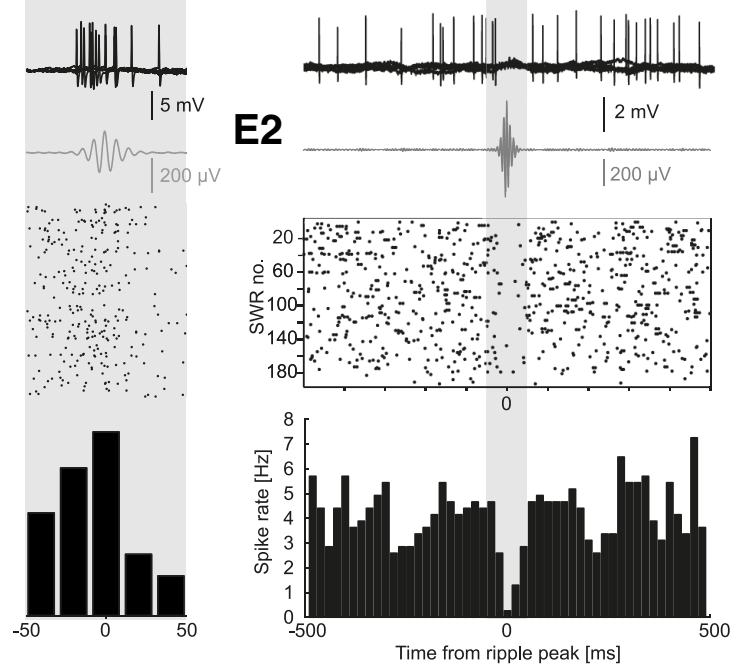
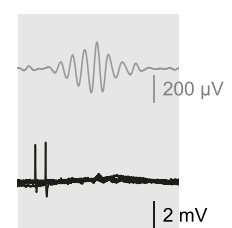

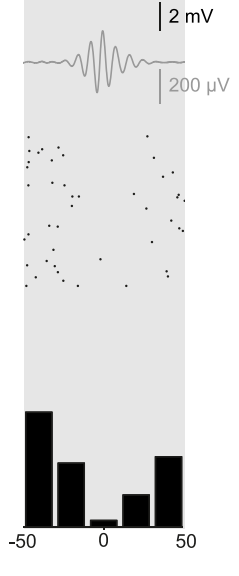

Figure 1. Subicular neurons are differentially modulated during ripples in awake mice. $A$, Recording configuration. $B$, Example ripple in simultaneous LFP recordings in area CA1 (gray) and the subiculum (green) during quiet wakefulness. Left, $0-10 \mathrm{kHz}$. Right, Same as left but bandpass filtered between $100 \mathrm{and} 220 \mathrm{~Hz}$. C, Power spectral density of the ripple peak-aligned averages from 35 LFP recordings. Gray lines indicate \pm SEM. $\boldsymbol{D}, \boldsymbol{E}$, Juxtacellular recordings in the subiculum with opposing spike modulation during CA1 ripples ( $\boldsymbol{D}$ and $\boldsymbol{E}$ represent one cell each). Zooms of the shaded areas are shown to the right. D1, E1, Top, Average of 5 ripples (LFP) aligned to the peak of the oscillation. Bottom, Overlay of corresponding juxtacellular recording. D2, E2, Top, Mean ripple LFP aligned to the peak of the oscillation. Middle, Raster plot of corresponding spikes. Each dot represents a spike. Each row represents all spikes that occur within $1 \mathrm{~s}$ (100 ms in zoom) around a ripple with its peak aligned to time point 0 . Bottom, Histograms of the above raster plot; time bins, $20 \mathrm{~ms}$.

data were stored using Igor Pro (Wavemetrics). The parvalbumin-positive interneuron shown in Figure 6B was reconstructed using the "Simple Neurite Tracer" (Longair et al., 2011).

\section{Connectivity}

The slices were prepared as described above. To ensure comparable slice condition and quality, we tested in each slice whether SWRs were generated and used only those slices in which this was the case. The temperature in the recording chamber was adjusted to $34^{\circ} \mathrm{C}$. Cells in the subiculum were identified using infrared differential contrast microscopy (BX51WI, Olympus) and selected within a distance of 50-100 $\mu \mathrm{m}$ from each other. In a subset of experiments, GAD67-GFP-expressing mice were used to aid the identification of interneurons. We performed somatic whole-cell patch-clamp recordings (pipette resistance 2.5-5 $\mathrm{m} \Omega$ ) of up to eight cells simultaneously. Each of the simultaneously recorded cells was consecutively stimulated with a train of 4 action potentials at $50 \mathrm{~Hz}$, elicited by 0.5 - to 2-ms-long current injections of 2-3.5 nA. For the characterization, increasing steps of current were injected ( 500 $\mathrm{ms}$, increment: $40-50 \mathrm{pA}$ ). The resting membrane potential of pyramidal cells was $-62.7 \pm 0.25 \mathrm{mV}$, that of fast-spiking interneurons $-64.4 \pm 1.3$ $\mathrm{mV}$, and that of non-fast-spiking interneurons $-62.5 \pm 0.9 \mathrm{mV}$ on average. In a few experiments, hyperpolarizing holding current was applied to keep the membrane potential at $-60 \mathrm{mV}$. The intracellular solution contained $135 \mathrm{~mm}$ potassium gluconate, $6 \mathrm{~mm} \mathrm{KCl,} 2 \mathrm{~mm} \mathrm{MgCl}_{2}$, $0.2 \mathrm{~mm}$ EGTA, $5 \mathrm{~mm} \mathrm{Na}$-phosphocreatine, $2 \mathrm{~mm} \mathrm{Na} \mathrm{Na}_{-} \mathrm{ATP}, 0.5 \mathrm{~mm}$ $\mathrm{Na}_{2}$-GTP, $10 \mathrm{~mm}$ HEPES buffer, and $0.2 \%$ biocytin. The $\mathrm{pH}$ was adjusted to 7.20 with $\mathrm{KOH}$. Recordings were performed using Multiclamp 700B amplifiers (Molecular Devices). Signals were filtered at $6 \mathrm{kHz}$, sampled at $20 \mathrm{kHz}$, and digitized using the Digidata 1440 and pClamp 10 (Molecular Devices).

\section{Data analysis}

Analysis of in vivo data. To detect ripples, the LFP signal was filtered with a Butterworth bandpass filter at $100-220 \mathrm{~Hz}$ in forward and reverse direction to prevent phase distortion. Any offset was corrected for by subtracting the mean. The absolute (i.e., rectified) value of the signal was smoothed using a Savitzky-Golay filter with a spanning window of 300 data points. A first threshold for the length of candidate events was set to 2 SDs of the smoothed and rectified signal. Positive detected events had to be above this threshold for a duration of at least $21 \mathrm{~ms}$. In these periods, maxima were detected that had to pass the criterion of 4.5 SDs of the filtered but not smoothed signal (detection is more adequate in the unflattened signal). In addition, a criterion for the minimum distance between the peaks of two events was used ( $40 \mathrm{~ms})$. In case of failure of this criterion, the ripple with the smaller peak was discarded. The sodetermined peaks of the ripples were used for alignment both of the LFP signal and the simultaneous single-cell recordings.

Spikes in whole-cell current-clamp recordings were detected with a thresholding algorithm on the ascending flank at $-20 \mathrm{mV}$, and the maximum in the following $2.5 \mathrm{~ms}$ was considered the peak. The signal had to fall below the threshold again, before a new spike was considered, which was relevant for spike detection in bursts. For spike detection in juxtacellular recordings, a similar algorithm was used where the threshold was set individually in each recording according to spike height. Cells with a peak to through width shorter than $0.4 \mathrm{~ms}$ were excluded as presumptive interneurons.

To generate the surrogate data for each cell, the number of ripples $n$ observed in the data was determined. Then, $n$ random time points were generated in ripple-free periods, and time windows of the same length as used to determine the spike count during ripples $(40 \mathrm{~ms})$ were used to 
A

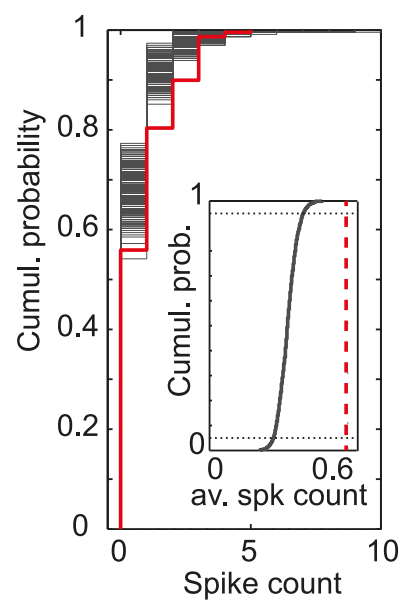

$n=229$ SWR events

$n=229 \times 1000$ surrogate events
B

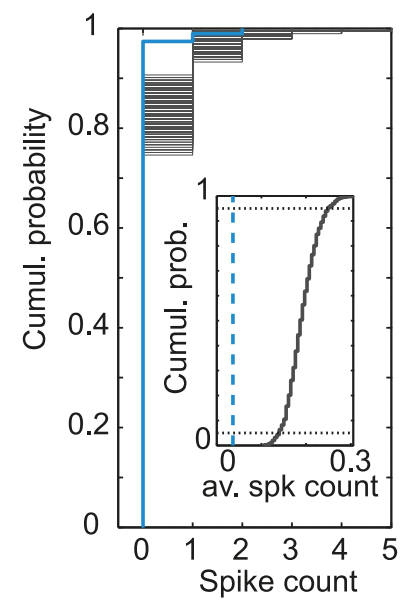

$n=193$ SWR events $n=193 \times 1000$ surrogate events
C

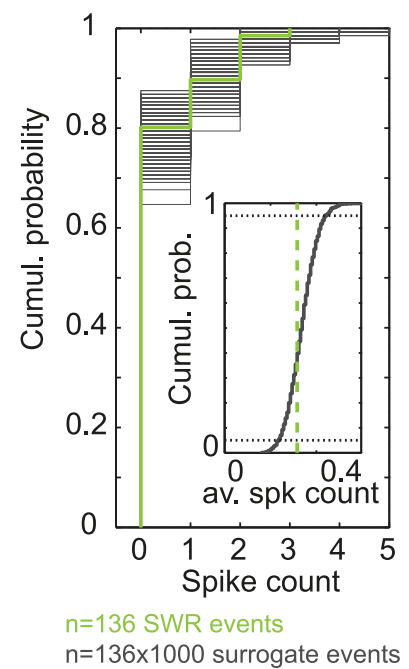

D

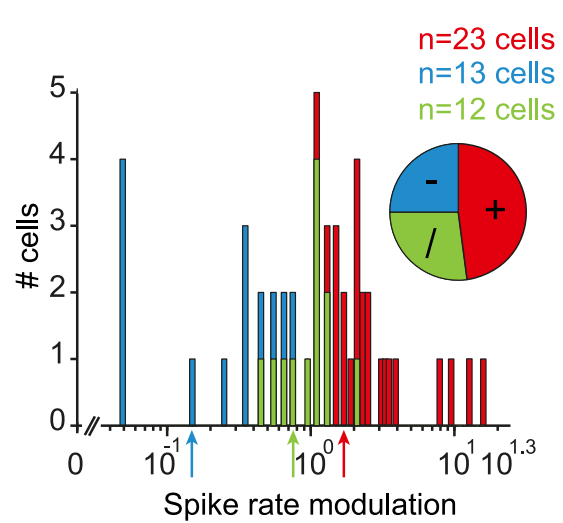

E

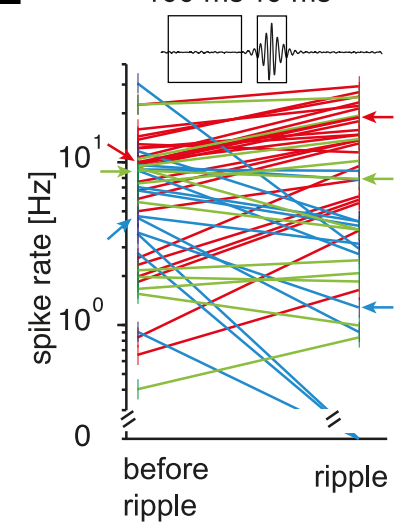

F 
a member of a burst if a preceding or following spike was within $8 \mathrm{~ms}$, meaning that also the last and first spike of a burst were considered members of the burst. The burst index was defined as the number of spikes in bursts divided by the number of remaining spikes (single spikes and doublets). For statistical comparison, the Mann-Whitney or the Wilcoxon signed-rank test was used. To test for normal distribution, the Lilliefors test was used.

Analysis of in vitro data. LFP SWRs recorded in area CA1 or in minislices of the subiculum were detected using a threshold-based algorithm. From simultaneously sampled voltageclamp data, $200 \mathrm{~ms}$ stretches of signal of SWRassociated postsynaptic currents were cut after alignment to the peak of the averaged postsynaptic currents of the respective recording; the postsynaptic current stretches were baselinecorrected by subtracting the mean of the first $75 \mathrm{~ms}$ in each window. For estimation of synaptic input during SWRs the total charge transfer was calculated by trapezoidal integration over the windows of data (trapz function in MATLAB, The MathWorks). The mean charge transfer values were calculated for each cell for comparison of synaptic input in regular and burst firing neurons. For statistical comparison of charge transfer and the ratio of excitatory and inhibitory charge transfer, the MannWhitney test or Student's $t$ test was used, as indicated.

Analysis of connectivity data. Cell subtypes were differentiated by monitoring the firing pattern at rheobase. Synaptic connections were identified when there was a postsynaptic potential corresponding to the presynaptic stimulation in the averaged trace from 40 to 50 sweeps. The $150 \mathrm{~ms}$ baseline just before the stimulation and the postsynaptic peak during the first action potential were used for the analysis of the EPSP/IPSP amplitudes with pClamp 10 (Molecular Devices). Only those pairs in which the first postsynaptic peak was clearly discernible were used for analysis of the amplitude. Postsynaptic potentials were clearly dis-

cernible from electrical crosstalk between electrodes by their relative timing, kinetics, and amplitudes. We used the Fisher's exact test for statistical comparison of the connection probabilities. The statistical significance of postsynaptic amplitudes was calculated using the MannWhitney test.

\section{Results}

\section{Pyramidal cells in the subiculum are functionally diverse in vivo}

LFP and simultaneous single-cell recordings were performed in awake head-fixed mice. The animals were habituated to the head fixation for a few days until they sat calmly for at least $1 \mathrm{~h}$. During the recordings, the animals were alert, they whisked, their eyes were always open, and they were mostly still during the recording (Crochet and Petersen, 2006). Ripples were recorded in the CA1 region of the hippocampus; they appeared as short (50-100 ms) aperiodic, recurrent events, and displayed a frequency peak at 120-150 Hz (Chrobak and Buzsáki, 1996) (Fig. 1A-C). With an additional electrode placed in the subiculum, we confirmed that ripples in CA1 and the subiculum occurred temporally coupled in our recording conditions (Chrobak and Buzsáki, 1994) (Fig.

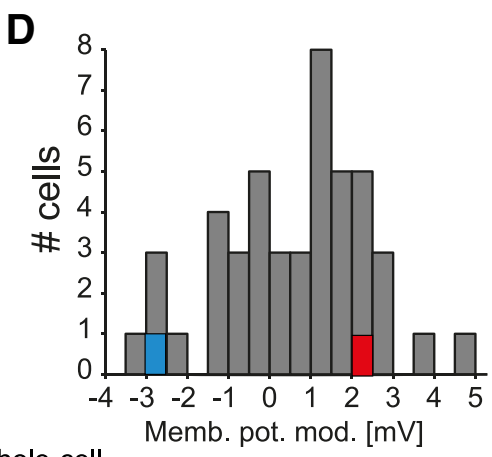

Subiculum whole-cell
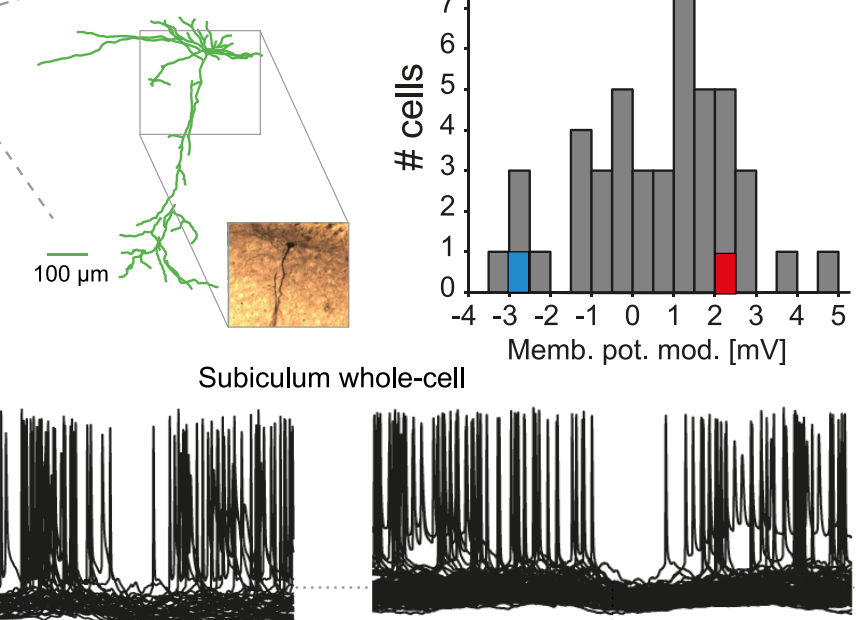

$30 \mathrm{mV}$

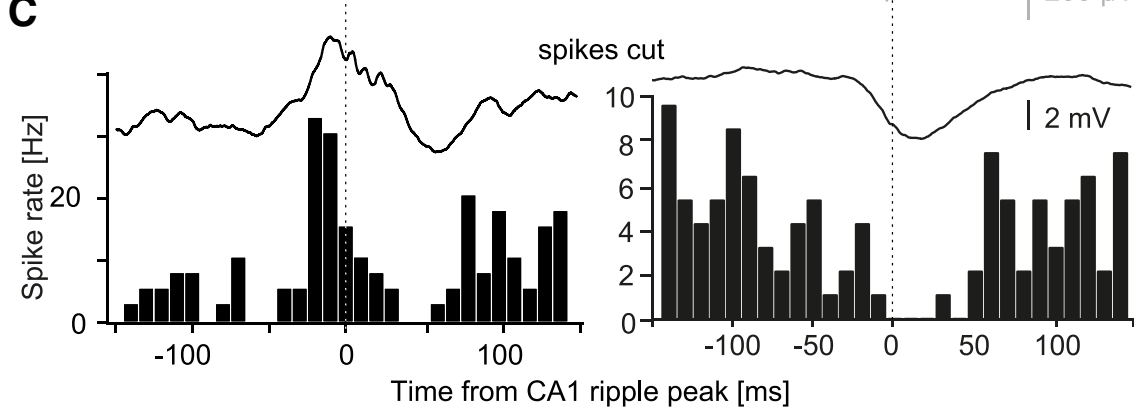

Figure 3. Pyramidal cells in the subiculum display depolarization or hyperpolarization during ripples. $\boldsymbol{A}$, Left, Coronal slice. Green represents the subiculum (adapted from Paxinos and Franklin, 2012). Right, Morphological reconstruction of a pyramidal cell in the subiculum recorded in vivo. Right, Bottom, Micrograph of the indicated area shows the stained cell in tissue. $B$, Examples of current-clamp recordings. Left and right columns represent one cell each. Top, Overlay of membrane potential traces aligned to the corresponding ripple peak of the LFP (left, 40 traces; right, 92 traces). Bottom, Mean ripple LFP. C, Top, Averages of the membrane potential with spikes cut. Bottom, Mean histogram of spike rate of the traces in $\boldsymbol{B}$; time bins, $10 \mathrm{~ms}$. D, Distribution of average membrane potential modulation of all cells recorded. The example cells shown in $B$ and $C$ are indicated by colored boxes.

$1 B)$. In the juxtacellular recording configuration, we then recorded from putative pyramidal cells (for details, see Materials and Methods) in the subiculum and correlated their activity with ripples in area CA1: we aligned the juxtacellular recording to the peak of the corresponding ripple oscillation to visualize any changes in discharge rate (Fig. $1 D, E$ ). We found cells in which the discharge rate increased during ripples, cells in which the discharge rate decreased, and cells in which it seemed unchanged. To quantify these opposing types of spike rate modulation, we generated for each cell a surrogate dataset, consisting of the spike counts in random time windows in ripple-free periods, and compared those with the spike count observed during ripples (for details, see Materials and Methods). A right shift in the observed cumulative distribution of the spike count (Fig. $2 A$, red line, corresponds to the cell shown in Fig. $1 D$ ) compared with the surrogate data (gray line(s)) indicates an increase in spike count and a left shift indicates a decrease (Fig. 2B, blue line, corresponds to the cell shown in Fig. 1E). Our analysis revealed indeed two subsets of cells that were opposingly modulated: some cells elicited more spikes and some cells elicited less spikes than expected from the surrogate dataset ( $n=23, n=13$, respectively). Twelve cells 
A

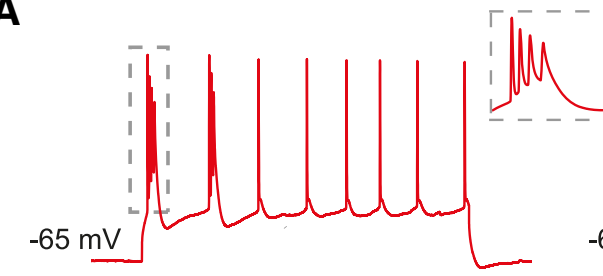

B

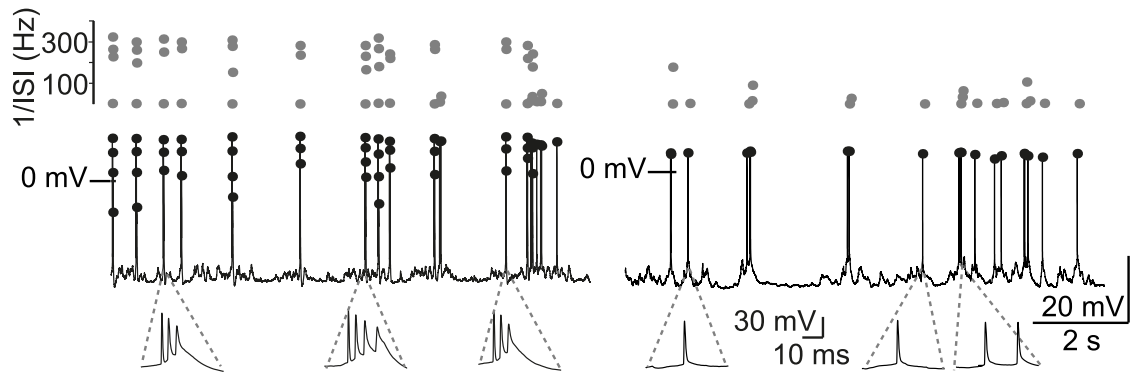

C

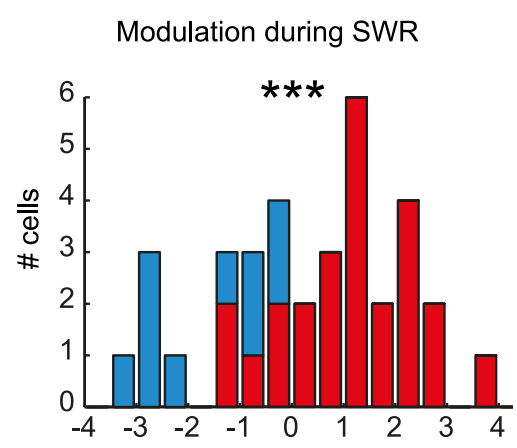

Membrane potential modulation [mV]
D

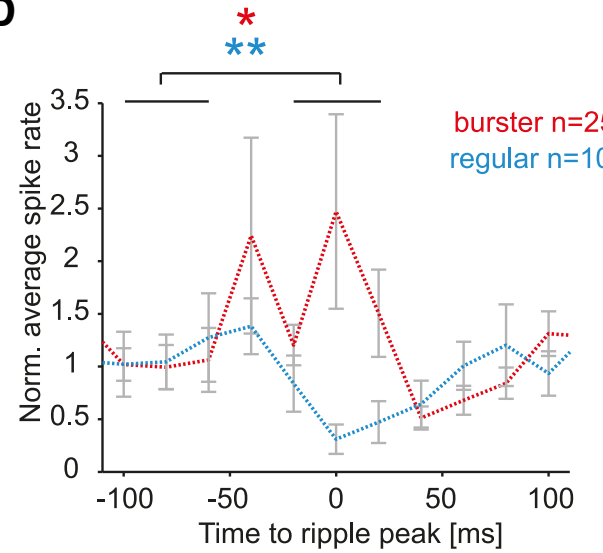

Figure 4. Subicular cell subtype predicts modulation during ripples in vivo. A, Firing pattern in response to $500 \mathrm{~ms}$ step current pulse in a burst (red) and a regular firing cell (blue). $B$, Ongoing network activity of the cells displayed in $A$. Black dots indicate peaks of spikes. Top, 1/interspike interval (gray dots). C, Distribution of membrane potential modulation in bursting (red) and regular (blue) firing cells. Cell subtype classification is solely based on the firing pattern at rheobase in response to step current pulses (for details, see Materials and Methods). The mean membrane potential modulation is significantly different from that of regular firing cells. ${ }^{* * *} p<0.001$ (Mann-Whitney test). $\boldsymbol{D}$, Time course of spike rate around the ripple peak. The average spike rate for each cell was normalized to its overall firing rate and the result averaged across all cells of bursting (red) or regular (blue) firing type, respectively. Time bins, $20 \mathrm{~ms}$. Error bars indicate SEM across cells. Significance was assessed as paired comparison of the average (not normalized) spike rate in the indicated bins before and during the ripple for all bursting cells (red asterisk) and all regular firing cells (blue asterisks). ${ }^{*} p<0.05$ (Wilcoxon signed-rank test). ${ }^{* *} p<0.01$ (Wilcoxon signed-rank test).

were not significantly modulated during ripples. In these cells, the spike rate observed was within the distribution of the randomly generated datasets (an example is shown in Fig. 2C). A summary of the spike rate modulation of all cells recorded is shown in Figure 2D, and a comparison of the spike rates before and during the ripple is shown in Figure 2E. The mean overall firing rate across all cells was $7.9 \pm 0.9 \mathrm{~Hz}$ and was similar in cells that were activated and cells that were silenced or not modulated during ripples $(7.1 \pm 1.1 \mathrm{~Hz}$, activated, $n=23 ; 9.8 \pm 2.1 \mathrm{~Hz}$, silenced, $n=13 ; 7.4 \pm 0.6 \mathrm{~Hz}$, not modulated, $n=12$; mean \pm SEM). The overall firing rate found here is in line with previous studies (Kim et al., 2012; Jackson et al., 2014) and is substantially higher than in other hippocampal or parahippocampal regions, such as the dentate gyrus, CA3, CA1, and entorhinal cortex (Mizuseki and Buzsáki, 2013). Furthermore, we analyzed the temporal structure of spiking as the ratio of number of spikes in bursts divided by the number of remaining spikes (burst index). The burst index, also in periods without ripples, was correlated with the spike rate modulation observed during ripples, pointing toward intrinsic differences in these cells (Fig. 2F; correlation coefficient $r=0.41, p=0.004)$.

To further investigate the rippleassociated modulation of discharge in subicular pyramidal cells, we performed whole-cell current-clamp recordings. These recordings were done under the same conditions as the juxtacellular recordings (i.e., in awake head-fixed mice). Similar to the procedure for the juxtacellular recordings, we aligned the membrane potential to the peak of the ripple oscillation. We found a subset of cells that displayed on average a depolarization during ripples, often followed by a hyperpolarization (Fig. $3 B, C$, left column). In a second subset of cells, we observed a hyperpolarization during the peak of the ripple oscillation (Fig. $3 B, C$, right column). To assess the membrane potential modulation during ripples, we subtracted the average of the membrane potential before and after the ripple peak ( -80 to $-40 \mathrm{~ms}$ and 40 to $80 \mathrm{~ms}$ ) for each cell from the average membrane potential during the ripple ( -20 to $20 \mathrm{~ms}$ ). The membrane potential modulation ranged from a clear depolarization to a clear hyperpolarization, whereas some cells were not clearly modulated (i.e., a membrane potential modulation close to zero, $n=46$ cells in total; Fig. 3D). Those depolarizations or hyperpolarizations were accompanied by an increase or decrease of spiking, respectively (Fig. $3 C$ ). The membrane potential modulation did not correlate with the initial membrane potential (i.e., the membrane potential registered at opening of the cell) $(r=0.08$, data not shown).

In addition to the possibility to monitor changes in membrane potential, whole-cell current-clamp recordings also allow for characterizing the firing pattern in response to step current pulses as routinely done in recordings in vitro. Subicular pyramidal cells in vitro exhibit either intrinsic bursting or regular spiking upon moderate depolarization (Taube, 1993). Therefore, we asked whether a similar distinction was present in vivo, and, if it was present, whether these distinct cell subtypes were consistent with the differential membrane potential modulation during ripples. To this end, we investigated the firing pattern in response to step current injections. Indeed, we observed differences in the responses of neurons due to $500 \mathrm{~ms}$ step current injections: at rheobase, we observed either one or several bursts of action potentials at the beginning of the step current pulse or we observed a more regular firing pattern consisting of single action potentials (Fig. 4A; in the following called bursting and regular firing cells, for details, see Materials and Methods). In line with their intrinsic discharge pattern, these cells also exhibited different firing patterns during ongoing spontaneous network activity, including 
periods outside of ripples: bursting cells fired often several closely timed action potentials and only few single spikes (Fig. $4 B)$; hence, the burst index was higher in bursting and lower in regular firing cells ( $0.98 \pm 0.34$, bursting cells, $n=25 ; 0.15 \pm$ 0.04 , regular firing cells, $n=9$; one cell was excluded from this analysis as it was entirely silent, during ongoing network activity, mean \pm SEM, Mann-Whitney test, $p=0.003$ ). Next, we asked whether the intrinsic discharge properties in response to step current pulses correlate with the differential modulation of the membrane potential and the differential discharge modulation during ripples. Indeed, the membrane potential modulation was negative for all regular firing cells $(n=10)$ and positive for most (20 of 25) bursting cells (Fig. $4 C$; i.e., all cells displaying a depolarization were burst firing cells, membrane potential modulation in bursting vs regular firing cells: $p<0.001$, Mann-Whitney test). The maximum depolarization of bursting cells was on average $6 \pm 4 \mathrm{~ms}$ before the ripple peak, and the minimum membrane potential in regular firing cells was on average $10.7 \pm 4.0$ $\mathrm{ms}$ after the ripple peak. Furthermore, the average spike rate decreased around the peak of the ripple for regular firing cells and increased for burst firing cells (Fig. $4 D$ ). These data confirm and extend our results from the juxtacellular recordings: juxtacellularly recorded cells with a decrease in spike rate during ripples likely correspond with regular firing cells and cells with an increase in spike rate correspond with the bursting phenotype of cells. This correspondence is also in line with a positive correlation of burst index and spike rate modulation in the juxtacellular recordings (Fig. $2 F$ ). Additionally, using a network-independent parameter for classification by depolarizing step current injections, we found in whole-cell recordings a higher burst index for bursting cells than for regular firing cells. Together, these experiments show that the burst firing subtype correlates with increased activity, whereas the regular firing subtype with decreased activity during ripples. Hence, we conclude that bursting and regular firing cells can act as functional distinct entities during ripples.

\section{Mechanisms of functional diversity assessed in vitro}

To disentangle whether the origin of this differential activation is intrinsic to the subiculum or governed by extrinsic (hippocampal or cortical) sources, we made use of an in vitro model of SWR in acute hippocampal slices (Hájos et al., 2009; Maier et al., 2009). We recorded the LFP SWR in area CA1 and postsynaptic currents in bursting and regular firing neurons in the subiculum (Fig. 5A).
B
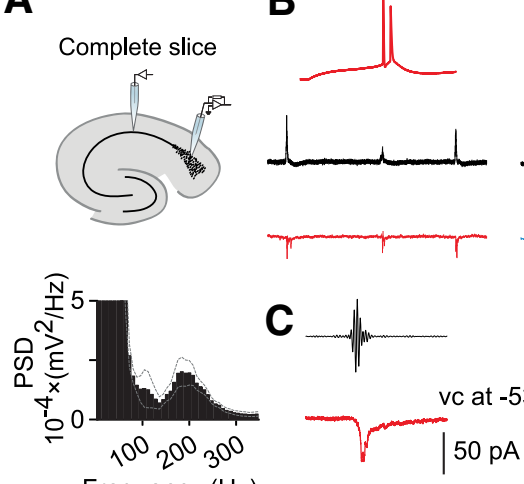

$50 \mathrm{pA}$

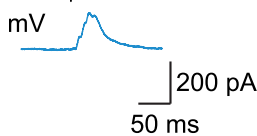

E
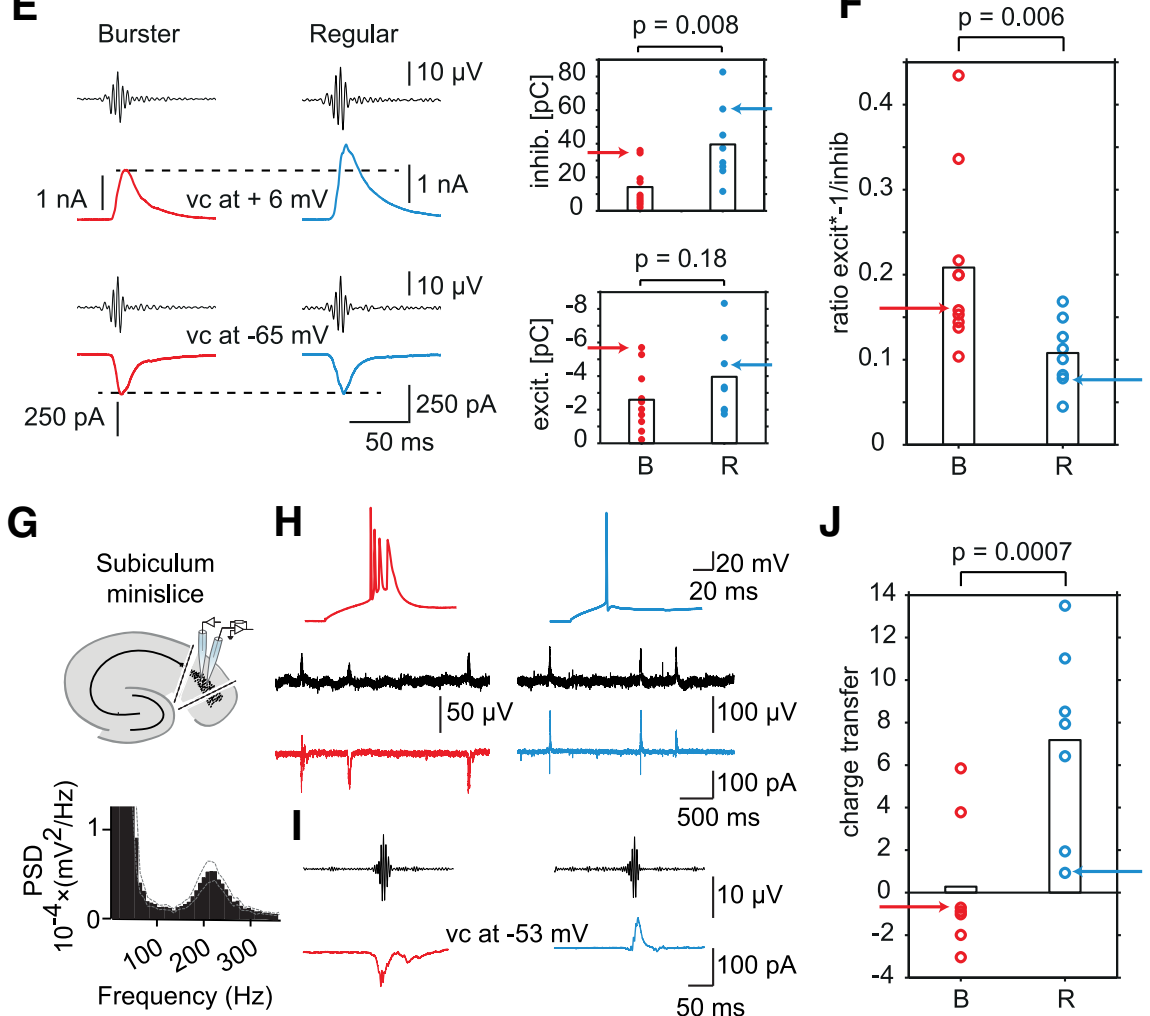
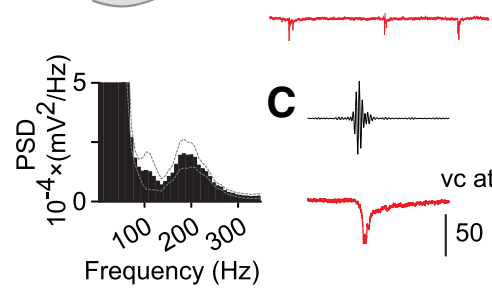

Figure 5. Bursting and regular firing cells are differentially engaged in SWRs in vitro. $A$, Top, Recording configuration: LFP in CA1 and simultaneous voltage-clamp recording in subicular cells. Bottom, Average power spectral density (PSD) of the data displayed in $\boldsymbol{B}$ (left, middle). $\boldsymbol{B}$, Top, Discharge patterns of a bursting (red) and a regular spiking cell (blue). Middle, Field potential SWR recorded in CA1 with associated synaptic currents (bottom). C, Averages (aligned to the ripple peak) of 20 CA1 ripples (filtered, $120-300 \mathrm{~Hz}$ ) and their postsynaptic currents (cells as in $\boldsymbol{B}$ ). $\boldsymbol{D}$, Left, Mean charge transfer values for regular and bursting neurons $(n=7$ and $n=8 ; p=0.02)$. E, Field potential SWR recorded in CA1 with associated synaptic currents recorded at $6 \mathrm{mV}$ and -65 $\mathrm{mV}$ using cesium-based intracellular solution in a bursting (red) and a regular firing cell (blue). Right, Summary of inhibitory and excitatory charge transfer in regular and bursting cells $(n=10$ and $n=8)$. $\boldsymbol{F}$, Ratios of averaged excitatory/inhibitory charge transfer for bursting and regular firing cells $(n=10$ and $n=8 ; p=0.006)$. $\mathbf{G}$, Recording configuration and PSD. $\boldsymbol{H}, \boldsymbol{I}$, Same as in $B, C$, but for subiculum minislice recordings. $J$, Mean charge transfer values for regular and bursting neurons $(n=7$ each; $p=$ 0.0007). Arrows indicate example traces.

Regular firing cells received primarily outward currents, whereas bursting cells received net inward currents during SWR (charge transfer in regular firing cells: $1.8 \pm 0.9 \mathrm{pC}, n=7$, bursting cells: $-1.1 \pm 0.4$ pC, $n=8, p=0.02$, Mann-Whitney test; Fig. $5 B-D$ ). To determine whether this difference in net currents arises from systematic differences of excitatory or inhibitory synaptic inputs or both, we performed voltage-clamp recordings at the reversal potentials of excitation and inhibition $(-65 \mathrm{mV}$ and $6 \mathrm{mV}$, for AMPA receptor- and GABAA receptor-mediated currents, re- 


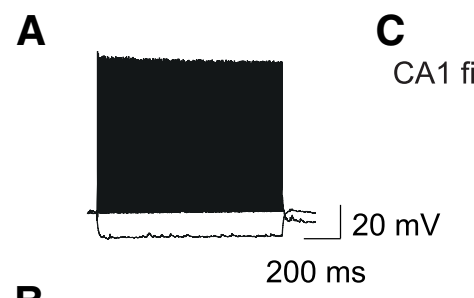

B

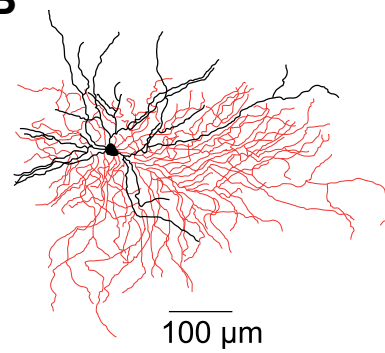

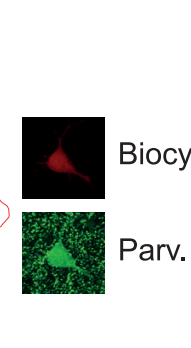

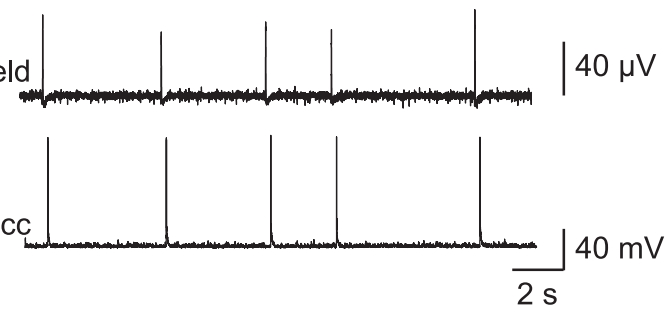

D

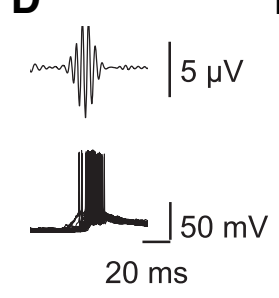

Figure 6. Fast-spiking interneurons are activated during SWR in vitro. $\boldsymbol{A}$, Firing pattern of a fast-spiking interneuron. $\boldsymbol{B}$, Left, Reconstruction of this cell. Black: dendrite; red: axon. Right, The cell was stained with biocytin and expressed parvalbumin. $C$, Top, LFP recorded in CA1. Bottom, Simultaneous current-clamp recording of the cell shown in $\boldsymbol{A}$ and $\boldsymbol{B}$. D. Left, Top, Averaged and aligned ripple oscillation. Bottom, Overlay of SWR-aligned current-clamp recording of this cell. $\boldsymbol{E}$, Fraction of SWR events in which spikes were emitted for all fast-spiking interneurons $(n=10)$; overlapping data points are horizontally shifted for better visualization.

spectively; Fig. 5E). Cells were briefly characterized by step current injection using potassium gluconate intracellular solution; hereafter, the patch pipette was gently withdrawn, and the same cell was repatched with cesium based intracellular solution to allow for improved voltage clamp and for clamping cells at positive potentials, which is a requirement to record at the reversal potential of AMPA receptors. Excitatory currents during SWR were comparable in regular $(-4.0 \pm 0.8 \mathrm{pC}, n=8)$ and burst firing cells $(-2.6 \pm 0.6 \mathrm{pC}, p=0.18, n=10$, unpaired Student's $t$ test). In contrast, we found that inhibitory currents associated with SWR were significantly larger in regular compared with burst firing cells (charge transfer: $39.6 \pm 8.1 \mathrm{pC}$ in regular firing cells vs $14.2 \pm 3.9 \mathrm{pC}$ in burst firing cells, $p=0.008$, unpaired Student's $t$ test; Fig. $5 E$, right). Accordingly, the ratio between the absolute value of excitation and inhibition was also significantly different in both subgroups of cells (Fig. $5 F ; 0.11 \pm 0.01$ in regular firing cells vs $0.21 \pm 0.03$ in bursting cells, $p=0.006$, MannWhitney test). Based on these findings, we conclude that the differential recruitment of bursting and regular firing cells during SWR arises mainly from a difference in the strength of synaptic inhibition onto those two subtypes. These data confirm and complement our in vivo results and demonstrate that, in the absence of cortical inputs, hippocampal signaling onto the subiculum is sufficient to differentially recruit subicular principal neurons. To probe whether this differential activation is inherited from the hippocampus or can be internally generated within the subiculum, we prepared minislices that only contained the subicular area (see Materials and Methods). Subicular minislice LFP recordings revealed spontaneous network oscillations in the ripple frequency range (Fig. 5G). Although the incidence was decreased in minislices compared with complete slices $(0.43 \pm 0.1$ event $/ \mathrm{s}$ in complete slices vs $0.15 \pm 0.0$ events/s in minislices), the oscillation frequency was largely similar $(205 \pm 6 \mathrm{~Hz}$ in complete slices vs $220 \pm 7 \mathrm{~Hz}$ in minislices). In voltage-clamp recordings, we found that regular firing cells primarily received net inhibitory currents during SWR, whereas in bursting cells net inputs were less positive or even negative, similar to recordings in whole slice conditions (charge transfer in regular firing cells: $7.2 \pm 1.7 \mathrm{pC}$,
E

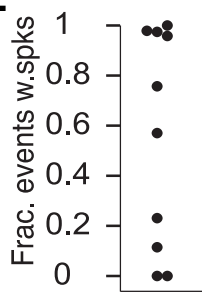

$n=7$, bursting cells: $0.2 \pm 1.2 \mathrm{pC}, n=7$, $p=0.0007$, Mann-Whitney test; Fig. 5 H$J)$. Hence, the differential recruitment of subicular principal cells appears to arise from within the subicular network and is likely to be mediated by a differential SWR-associated inhibitory signaling onto burst versus regular firing cells.

Therefore, we next investigated in complete slices the recruitment of one major class of inhibitory interneurons, the parvalbumin-expressing fast-spiking interneurons, during SWR (Fig. 6A,B). Voltage-clamp recordings revealed strong excitatory input during SWR onto these cells, charge transfer: $-11.03 \pm 3.9 \mathrm{pC}$ on average $(n=9)$. In line with this, most cells elicited spontaneous spikes during SWR (8 of 10 cells; Fig. $6 C, D, E$ ). The fraction of events per cell in which spikes were evoked was on average $0.56 \pm 0.14(n=$ $10)$. We conclude that fast-spiking interneurons are a likely source of the inhibitory currents observed in pyramidal cells during SWR and might contribute to the differential modulation of bursting and regular firing cells during SWR.

To test whether the functional differences we found during SWR in vivo and in vitro are reflected in the local network topology, we established multiple simultaneous recordings of pyramidal cells and interneurons (Fig. 7A). We performed up to eight parallel recordings of subicular pyramidal neurons and interneurons and tested their synaptic connection probability as well as their transmission properties. In total, we recorded 245 regular spiking pyramidal cells, 200 bursting cells, and 149 interneurons, of which 85 were fast-spiking interneurons. We elicited four action potentials at $50 \mathrm{~Hz}$ in the presynaptic cell, which led to EPSPs or IPSPs in the postsynaptic cell if they were connected (Fig. $7 B, C)$. Among bursting neurons, we found a connection probability of $3.7 \%$ (15 of 408 ), similar to that among regular firing cells: $4.7 \%$ (28 of 592), whereas the projections from regular onto bursting cells were more numerous, $7.3 \%$ (13 of 179). In stark contrast, we found no connection in the opposite direction ( 0 of 181; Fig. 7E, left). In addition, we analyzed the amplitudes of the EPSP evoked from the first action potential in connected pairs. In some connected pairs, a clear EPSP was only discernible after more than one action potential and is therefore not included in the analysis. The amplitudes of EPSPs from the first action potential were larger in regular to burst firing cell connections $(0.5 \pm 0.2 \mathrm{mV}, n=10)$ compared with connections among burst firing cells $(0.1 \pm 0.0 \mathrm{mV}, n=14, p<0.05$, Mann-Whitney test). The amplitude among regular firing cells was $0.3 \pm 0.1 \mathrm{mV}(n=$ 23; Fig. 7F, left). Together, these data show that the local excitatory wiring of the subiculum is not random but is ruled by subtype-specific connection probabilities.

As a pyramidal cell subtype-specific inhibitory wiring scheme might contribute to the different modulation of burst and regular firing cells during SWR, we next investigated connection probabilities among interneurons and pyramidal cells. Indeed, we found that the inhibitory connections onto regular firing cells were more numerous than onto bursting cells (35\%, 81 of 229 interneuron to bursting cells vs $46 \%$, 95 of 208 interneuron to regular firing cells, $p=0.03$, Fisher's exact test; Fig. $7 E)$. The 

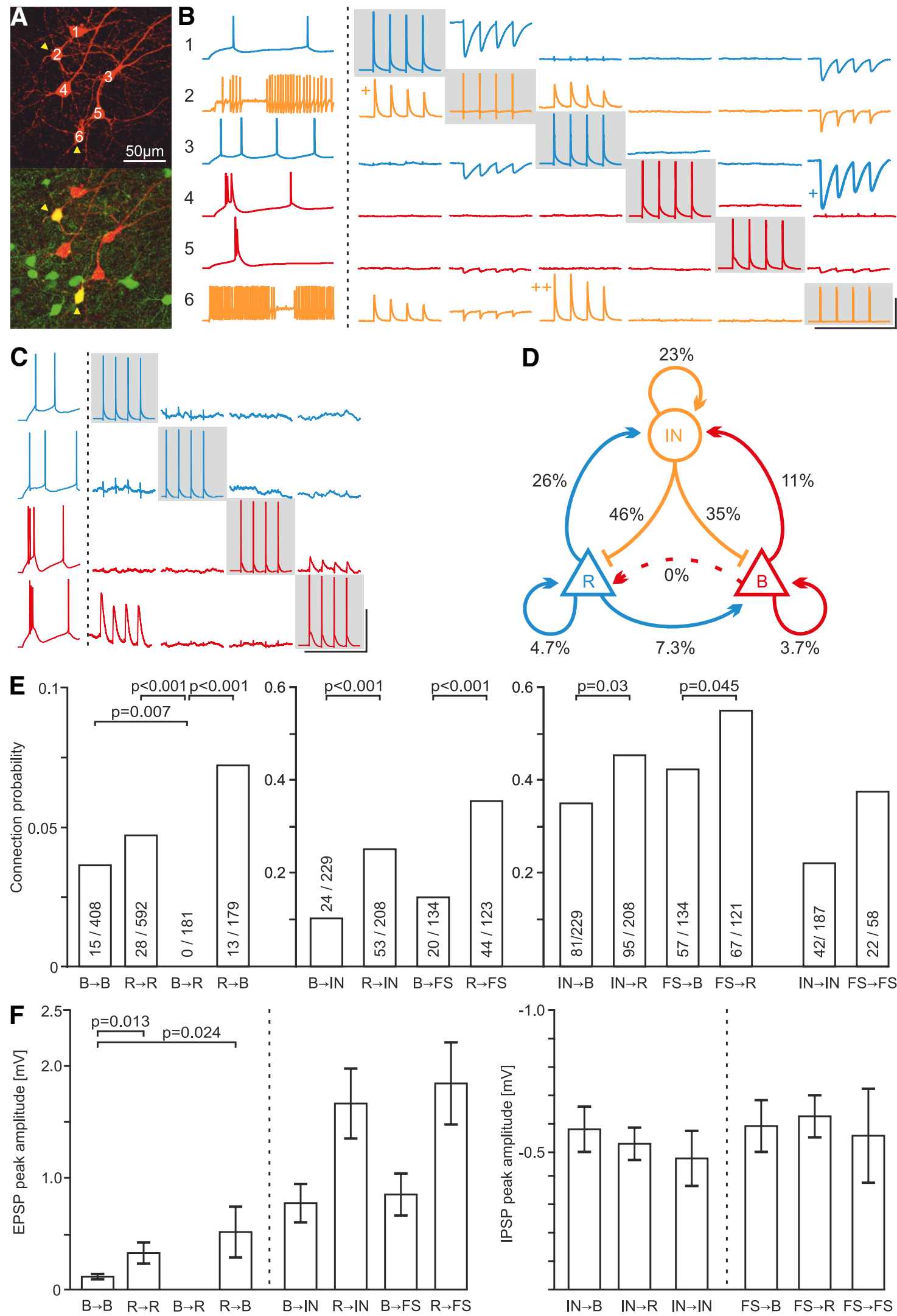

Figure 7. Subtype-specific connection probability and synaptic strength. $A$, Biocytin staining of six cells recorded simultaneously (top). Using GAD67-eGFP transgenic mice (bottom, interneurons in green), two interneurons (bottom, orange arrowheads) and four pyramidal cells were identified. $\boldsymbol{B}$, Recorded traces in current-clamp mode. The firing pattern at rheobase is used for cell (sub)type classification (left). Blue represents regular firing pyramidal cells. Yellow represents interneurons. Red represents bursting pyramidal cells. Each neuron is consecutively stimulated with 4 action potentials (gray boxes). The postsynaptic responses are shown in the same column. Calibration: horizontal, $250 \mathrm{~ms}$; vertical: $2 \mathrm{mV} ;+, 4 \mathrm{mV} ;++, 8 \mathrm{mV}, 50 \mathrm{mV}$ for action potentials. C, Example traces of excitatory connections between pyramidal cells. Left, Firing patterns. Calibration: horizontal, $250 \mathrm{~ms}, 200 \mathrm{~ms}$ for firing pattern; vertical, $0.5 \mathrm{mV}, 50 \mathrm{mV}$ for action potentials. Because of close positioning of the patch pipettes, stimulation artifacts are sometimes registered on other channels. D, Scheme of the subtype-specific connection (Figure legend continues.) 
amplitude of interneuron to regular firing pyramidal cell connections was $-0.5 \pm 0.1 \mathrm{mV}(n=79)$, and the amplitude of interneuron to bursting pyramidal cells was $-0.6 \pm 0.1 \mathrm{mV}$ $(n=77)$ (Figure $7 F$, right). Furthermore, inhibitory interneurons received more connections from regular firing cells $(26 \%, 53$ of 208) than from burst firing cells $(11 \%, 24$ of $229, p<0.001$, Fisher's exact test; Fig. 7E). The postsynaptic amplitudes from regular firing and burst firing cells onto interneurons were simi$\operatorname{lar}(1.7 \pm 0.3 \mathrm{mV}, n=53$, vs $0.8 \pm 0.2 \mathrm{mV}, n=23$, respectively, $p=0.081$, Mann-Whitney test; Figure $7 F)$. As the inhibitory input during SWR is likely to stem from fast-spiking interneurons, we analyzed the connection probability of subicular pyramidal cells and fast-spiking interneurons separately. Indeed, we found that fast-spiking interneurons project more often onto regular firing cells (55\%, 67 of 121) than onto bursting cells (43\%, 57 of $134, p=0.045$, Fisher's exact test; Fig. $7 E$ ). The postsynaptic amplitudes from fast-spiking interneurons to regular firing cells was $-0.6 \pm 0.1 \mathrm{mV}(n=55)$ and to burst firing cells $-0.6 \pm 0.1$ $\mathrm{mV}(n=53)(p=0.117$, Mann-Whitney test; Figure $7 F)$. A summary of the connection probabilities is shown in Figure $7 D$. These data suggest that the functional diversity of burst and regular firing pyramidal cells might be enabled by the subtypespecific local network topology.

\section{Discussion}

Using whole-cell patch-clamp recordings, we have shown here that bursting and regular firing cells in the subiculum are discernible in vivo. Further, we show that these two pyramidal cell subpopulations exhibit a functional difference: burst firing cells are activated, whereas the firing probability of regular firing cells is reduced during ripples. In line with this, we found that, in SWRassociated synaptic inputs, the ratio of excitation to inhibition is larger for bursting than for regular firing cells. Whereas it has been shown that the strength of pyramidal cell activation in CA1 can vary depending on their anatomical position within the pyramidal cell layer (Mizuseki et al., 2011), we show here that in the subiculum only a subset of cells, the bursting cells, are activated while another subset is inhibited (Eller et al., 2015). Because SWRs have been shown to be important for learning of spatial memory tasks, and only the burst firing cells are activated during SWR, it is likely that this population of cells transmits mostly spatial information, whereas regular firing cells might contribute to the transmission of nonspatial contents. Moreover, considering the different preferential extrahippocampal target areas of burst and regular firing cells (Kim and Spruston, 2012), we assume that mainly target regions of the burst firing cells receive excitatory input from the subiculum during SWR. Indeed, neuronal activity that is temporally locked to hippocampal sharp waves could be shown in both the medial entorhinal cortex (Chrobak and Buzsáki, 1994; Wu et al., 2006) and the presubiculum (Chrobak and Buzsáki, 1994), which are target areas of burst firing cells (Kim and Spruston, 2012). It is tempting to speculate that there is no or less SWR-associated input to the lateral entorhinal cortex, a target area mostly innervated by regular firing cells. This would imply a pivotal role of the subiculum

$\leftarrow$

(Figure legend continued.) probabilities in the subiculum. $\boldsymbol{E}$, Connection probability between the different subtypes determined as the number of connected pairs divided by the number of tested connections. No connections were found projecting from bursting to regular firing pyramidal cells. B, Burst firing cell; R, regular firing cell; IN, interneurons; FS, fast-spiking interneurons. Statistical test: Fisher's exact test. $\boldsymbol{F}$, Mean of postsynaptic potential amplitudes. Error bars indicate SEM. Statistical test: Mann-Whitney test. in separating information streams and distributing this information to cortical targets. Furthermore, recent studies demonstrated that the canonical flow of information from CA3 via CA1 to the subiculum can be reversed during theta oscillations in intact hippocampal preparations as well as in vivo (Jackson et al., 2014) and that the subiculum might receive input from entorhinal cortex during SWR (Norimoto et al., 2013). Together with anatomical data, the influence of the subiculum on "upstream" target regions is likely to be stronger than previously anticipated (Sun et al., 2014).

Our analysis of the neuronal network topology revealed that the subtype-specific functional differences observed during SWR are also reflected in the local network wiring: the subiculum exhibits an excitatory network with unidirectional connectivity between regular and bursting cells. A local network topology that is determined by long-range projection targets has been described recently in the cortex. Principal cells that either project to the same target region or to different target regions can be preferentially connected (Morishima and Kawaguchi, 2006; Brown and Hestrin, 2009; Morishima et al., 2011). Here, we find that principal cells that project to the same target regions are connected among themselves; in addition, there is exclusive unidirectional connectivity from one group of principal cells, regular firing cells, to the other, burst firing cells, but not vice versa. This shows that functional specialization and long-range targets are closely linked to local network topology.

Our findings from the minislice experiments suggest that the local network of the subiculum is able to generate the subtypespecific modulation by itself. Furthermore, we show here that burst firing cells are preferentially activated and that there is a high connection probability between regular and bursting cells. However, it seems unlikely that the strong unidirectional regular to burst firing connection can explain the preferential activation during ripples because we do not have evidence for activation of regular firing cells during ripples. Nevertheless, we cannot exclude the possibility that a fraction of regular firing cells is activated and might aid the initiation of ripple events. Our data suggest that regular firing cells receive stronger inhibitory inputs during SWR than burst firing pyramidal cells. By multiple patchclamp recordings, we could further show that the local subicular network favors inhibition onto regular firing cells. These findings are in contrast to the previously described homogeneous inhibitory innervation found in neocortex (Packer and Yuste, 2011) but in line with the subtype-specific innervation described for entorhinal cortex (Varga et al., 2010), CA1 (Lee et al., 2014), and the striatum (Gittis et al., 2010). For the subiculum, this subtype specificity of inhibitory connections is likely to endow functional preference of burst and regular firing cells during ripples.

\section{References}

Amaral DG, Dolorfo C, Alvarez-Royo P (1991) Organization of CA1 projections to the subiculum: a PHA-L analysis in the rat. Hippocampus 1:415-435. CrossRef Medline

Behr J, Wozny C, Fidzinski P, Schmitz D (2009) Synaptic plasticity in the subiculum. Prog Neurobiol 89:334-342. CrossRef Medline

Brown SP, Hestrin S (2009) Intracortical circuits of pyramidal neurons reflect their long-range axonal targets. Nature 457:1133-1136. CrossRef Medline

Buzsáki G (1986) Hippocampal sharp waves: their origin and significance. Brain Res 398:242-252. CrossRef Medline

Chrobak JJ, Buzsáki G (1994) Selective activation of deep layer (v-vi) retrohippocampal cortical neurons during hippocampal sharp waves in the behaving rat. J Neurosci 14:6160-6170. Medline

ChrobakJJ, Buzsáki G (1996) High-frequency oscillations in the output net- 
works of the hippocampal-entorhinal axis of the freely behaving rat. J Neurosci 16:3056-3066. Medline

Crochet S, Petersen CC (2006) Correlating whisker behavior with membrane potential in barrel cortex of awake mice. Nat Neurosci 9:608-610. CrossRef Medline

Davidson TJ, Kloosterman F, Wilson MA (2009) Hippocampal replay of extended experience. Neuron 63:497-507. CrossRef Medline

Ego-Stengel V, Wilson MA (2010) Disruption of ripple-associated hippocampal activity during rest impairs spatial learning in the rat. Hippocampus 20:1-10. CrossRef Medline

Eller J, Zarnadze S, Bäuerle P, Dugladze T, Gloveli T (2015) Cell typespecific separation of subicular principal neurons during network activities. PLoS One 10:e0123636. CrossRef Medline

Girardeau G, Benchenane K, Wiener SI, Buzsáki G, Zugaro MB (2009) Selective suppression of hippocampal ripples impairs spatial memory. Nat Neurosci 12:1222-1223. CrossRef Medline

Gittis AH, Nelson AB, Thwin MT, Palop JJ, Kreitzer AC (2010) Distinct roles of GABAergic interneurons in the regulation of striatal output pathways. J Neurosci 30:2223-2234. CrossRef Medline

Graves AR, Moore SJ, Bloss EB, Mensh BD, Kath WL, Spruston N (2012) Hippocampal pyramidal neurons comprise two distinct cell types that are countermodulated by metabotropic receptors. Neuron 76:776-789. CrossRef Medline

Hájos N, Ellender TJ, Zemankovics R, Mann EO, Exley R, Cragg SJ, Freund TF, Paulsen O (2009) Maintaining network activity in submerged hippocampal slices: importance of oxygen supply. Eur J Neurosci 29:319327. CrossRef Medline

Inostroza M, Born J (2013) Sleep for preserving and transforming episodic memory. Annu Rev Neurosci 36:79-102. CrossRef Medline

Jackson J, Amilhon B, Goutagny R, Bott JB, Manseau F, Kortleven C, Bressler SL, Williams S (2014) Reversal of theta rhythm flow through intact hippocampal circuits. Nat Neurosci 17:1362-1370. CrossRef Medline

Jadhav SP, Kemere C, German PW, Frank LM (2012) Awake hippocampal sharp-wave ripples support spatial memory. Science 336:1454-1458. CrossRef Medline

Ji D, Wilson MA (2007) Coordinated memory replay in the visual cortex and hippocampus during sleep. Nat Neurosci 10:100-107. CrossRef Medline

Karlsson MP, Frank LM (2009) Awake replay of remote experiences in the hippocampus. Nat Neurosci 12:913-918. CrossRef Medline

Katona L, Lapray D, Viney TJ, Oulhaj A, Borhegyi Z, Micklem BR, Klausberger T, Somogyi P (2014) Sleep and movement differentiates actions of two types of somatostatin-expressing gabaergic interneuron in rat hippocampus. Neuron 82:872-886. CrossRef Medline

Kim SM, Ganguli S, Frank LM (2012) Spatial information outflow from the hippocampal circuit: distributed spatial coding and phase precession in the subiculum. J Neurosci 32:11539-11558. CrossRef Medline

Kim Y, Spruston N (2012) Target-specific output patterns are predicted by the distribution of regular-spiking and bursting pyramidal neurons in the subiculum. Hippocampus 22:693-706. CrossRef Medline

Lee AK, Wilson MA (2002) Memory of sequential experience in the hippocampus during slow wave sleep. Neuron 36:1183-1194. CrossRef Medline

Lee SH, Marchionni I, Bezaire M, Varga C, Danielson N, Lovett-Barron M, Losonczy A, Soltesz I (2014) Parvalbumin-positive basket cells differentiate among hippocampal pyramidal cells. Neuron 82:1129-1144. CrossRef Medline

Logothetis NK, Eschenko O, Murayama Y, Augath M, Steudel T, Evrard HC, Besserve M, Oeltermann A (2012) Hippocampal-cortical interaction during periods of subcortical silence. Nature 491:547-553. CrossRef Medline

Longair MH, Baker DA, Armstrong JD (2011) Simple neurite tracer: open source software for reconstruction, visualization and analysis of neuronal processes. Bioinformatics 27:2453-2454. CrossRef Medline

Maier N, Morris G, Johenning FW, Schmitz D (2009) An approach for re- liably investigating hippocampal sharp wave-ripples in vitro. PLoS One 4:e6925. CrossRef Medline

Maier N, Tejero-Cantero A, Dorrn AL, Winterer J, Beed PS, Morris G, Kempter R, Poulet JF, Leibold C, Schmitz D (2011) Coherent phasic excitation during hippocampal ripples. Neuron 72:137-152. CrossRef Medline

Markram H, Lübke J, Frotscher M, Sakmann B (1997) Regulation of synaptic efficacy by coincidence of postsynaptic APs and EPSPs. Science 275: 213-215. CrossRef Medline

Marshall L, Helgadóttir H, Mölle M, Born J (2006) Boosting slow oscillations during sleep potentiates memory. Nature 444:610-613. CrossRef Medline

Mehta MR (2007) Cortico-hippocampal interaction during up-down states and memory consolidation. Nat Neurosci 10:13-15. CrossRef Medline

Mizuseki K, Buzsáki G (2013) Preconfigured, skewed distribution of firing rates in the hippocampus and entorhinal cortex. Cell Rep 4:1010-1021. CrossRef Medline

Mizuseki K, Diba K, Pastalkova E, Buzsáki G (2011) Hippocampal cal pyramidal cells form functionally distinct sublayers. Nat Neurosci 14:11741181. CrossRef Medline

Morishima M, Kawaguchi Y (2006) Recurrent connection patterns of corticostriatal pyramidal cells in frontal cortex. J Neurosci 26:4394-4405. CrossRef Medline

Morishima M, Morita K, Kubota Y, Kawaguchi Y (2011) Highly differentiated projection-specific cortical subnetworks. J Neurosci 31:1038010391. CrossRef Medline

Naber PA, Witter MP (1998) Subicular efferents are organized mostly as parallel projections: a double-labeling, retrograde-tracing study in the rat. J Comp Neurol 393:284-297. CrossRef Medline

Naber PA, Witter MP, Silva FHL (2000) Networks of the hippocampal memory system of the rat: the pivotal role of the subiculum. Ann N Y Acad Sci 911:392-403. CrossRef Medline

Norimoto H, Matsumoto N, Miyawaki T, Matsuki N, Ikegaya Y (2013) Subicular activation preceding hippocampal ripples in vitro. Sci Rep 3:2696. CrossRef Medline

O'Keefe J, Nadel L (1978) The hippocampus as a cognitive map. Oxford: Oxford UP.

Packer AM, Yuste R (2011) Dense, unspecific connectivity of neocortical parvalbumin-positive interneurons: a canonical microcircuit for inhibition? J Neurosci 31:13260-13271. CrossRef Medline

Paxinos G, Franklin K (2012) The mouse brain in stereotactic coordinates, Ed 4. San Diego: Academic.

Sun Y, Nguyen AQ, Nguyen JP, Le L, Saur D, Choi J, Callaway EM, Xu X (2014) Cell-type-specific circuit connectivity of hippocampal CA1 revealed through Cre-dependent rabies tracing. Cell Rep 7:269-280. CrossRef Medline

Taube JS (1993) Electrophysiological properties of neurons in the rat subiculum in vitro. Exp Brain Res 96:304-318. Medline

Varga C, Lee SY, Soltesz I (2010) Target-selective gabaergic control of entorhinal cortex output. Nat Neurosci 13:822-824. CrossRef Medline

Wilhelm I, Rose M, Imhof KI, Rasch B, Büchel C, Born J (2013) The sleeping child outplays the adult's capacity to convert implicit into explicit knowledge. Nat Neurosci 16:391-393. CrossRef Medline

Witter MP (2006) Connections of the subiculum of the rat: topography in relation to columnar and laminar organization. Behav Brain Res 174:251264. CrossRef Medline

Witter MP, Ostendorf RH, Groenewegen HJ (1990) Heterogeneity in the dorsal subiculum of the rat: distinct neuronal zones project to different cortical and subcortical targets. Eur J Neurosci 2:718-725. CrossRef Medline

Wu CP, Huang HL, Asl MN, He JW, Gillis J, Skinner FK, Zhang L (2006) Spontaneous rhythmic field potentials of isolated mouse hippocampalsubicular-entorhinal cortices in vitro. J Physiol 576:457-476. CrossRef Medline 